\title{
PERANAN AIR DALAM PERSPEKTIF AL-QURAN (Air Sebagai Sumber Kehidupan)
}

\author{
Mochamad Imamudin \\ Fakultas Sains \& Teknologi UIN Maliki Malang \\ Email: mochimamudin@gmail.com
}

\begin{abstract}
Abstrak.
Air merupakan kebutuhan pokok dan esensial bagi manusia dan makhluk hidup di muka bumi ini, oleh karena itu keberadaannya merupakan anugerah teragung yang dilimpahkan Allah Swt kepada seluruh makhluknya, sebab dengan air Allah menghidupkan segala makhluk di atas bumi ini, menyebarkan rejeki melalui pemanfaatannya sebagai zat yang menumbuhkan tanaman, sebagai minuman bagi binatang ternak dan bahkan sebagai sumber energi yang dapat diperbaharui. Disisi lain air juga dapat mendatangkan bahaya dan bencana besar bagi ekosistem makhluk hidup di muka bumi ini seperti datangnya banjir, air pasang di tepi laut dan longsor. Namun datangnya bencana tersebut apakah disebabkan oleh kesalahan alam ataukah manusia yang salah mengelola alam ini. Maka pada penelitian ini penulis akan mengungkap bagaimana pandangan al-Quran tentang air dari segi manfaatnya sebagai sumber kehidupan sehingga dapat menambah wawasan tentang air dari perspektif al-Quran.
\end{abstract}

Kata Kunci : Air, Kehidupan, Al-Quran

\section{PENGANTAR}

Sains dan teknologi adalah lapangan kegiatan yang terus-menerus berkembang karena mempunyai manfaat sebagai penunjang kehidupan manusia. Berkat hasil sains dan teknologi banyak segi kehidupan itu menjadi lebih mudah. Penemuan-penemuan baru di bidang sainstek modern dan pemanfaatan Sumber Daya Alam (SDA) telah mengantarkan manusia menjadi hedonisme yang mengandalkan kenikmatan semata tanpa melihat dampak dan efeknya.

Dengan demikian tanpa disadari bahwa penguasaan dan pengembangan sains dan teknologi modern dengan sikap yang demikian telah meninggalkan nilai-nilai keagamaan terutama terkait etika lingkungan. Sehingga muncul pandangan antroposentris-sekuler bahwa manusia adalah ciptaan Tuhan yang istimewa sehingga berhak ntuk menguasai alam dan mengeksploitasinya, seperti eksploitasi air tanpa adanya perbaikan dan konservasi kembali. Sehingga hilanglah sifat tawazun dan kesetabilan interaksi antara manusia dengan alam, sehingga muncul berbagai kondisi ketidaksetabilan dalam lingkungan dan inilah merupakan bentuk kedzaliman serta kelalaian manusia.

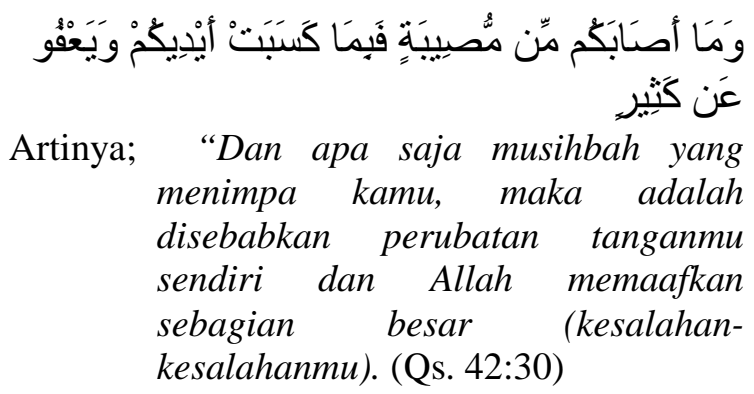

Padahal menurut pandangan Islam alam ini memiliki keterarahan, kebertujuan untuk melayani kehendak Ilahi, Alam ini diciptakan bukanlah dengan sia-sia dan kebetulan. Tetapi dibuat dengan sebuah perencanaan yang sempurna dan teratur. Agar manusia melakukan kebaikan dan mencapai kebahagiaan. Hal ini dapat dicapai dengan syarat; pertama, bahwa alam ini bukanlah milik manusia tetapi milik Tuhan, layaknya seorang penyewa tanah, manusia harus turut menjaga keseimbangan alam milik tuannya. Karena Allah memberikan alam ini sebagai amanat. Sehingga manusia tidak memakan jatah generasi yang akan datang. (Isma'il Raji, 1988)

Dan juga harus ditopang dengan tolok ukur konseptual lainnya seperti keadilan, I'tidal (keseimbangan), istihsan (mengambil sesuatu yang lebih baik) dan istishlah (untuk kemaslahatan umum) inilah kerangka kerja yang dapat meminimalisir eksploitasi manusia dalam memanfaatkan SDA. 
MAKNA AIR DALAM PRESPEKTIF ALQURAN

Kata air dalam Al-Quran disebutkan dalam bentuk mufrad (tunggal) yaitu (مَاء) $M a$ ' dan tidak disebutkan dalam bentuk jamak (أمْوَاه) (َمَاه) amwah atau (مِيَّ) miyah. Dan terulang sebanyak 63 kali dalam 41 surah. Yaitu; al-Baqarah;22, 74, 164., an-Nisa'; 43., al-Ma'idah;6., alAn'am: 99., al-A'raf: 50, 57., Al-Anfal: 11., Yunus: 24., Hud: 7, 43, 44., ar-Ra'd: 4, 14, 17. , Ibrahim 16, 32., al-Hijr: 22, an-Nahl: 10, 65., al-Kahfi: 29, 41, 45., Taha: 53., al-Anbiya': 30, al-Haj: 5, 63., al-Mu'minun: 18., an-Nur: 45., al-Furqan: 48, 54., an-Naml: 60., al-Qasas: 23., al-Ankabut: 63, ar-Rum: 24., Luqman: 10., as-Sajadah: 8, 27., Fatir: 27., az-Zumar: 21., Fussilat: 39., az-Zukhruf: 11., Muhammad: 15., Qaf: 9., al-Qamar: 11, 12, 28., al-Waqi'ah: 31, 68., al-Muluk: 30., al-Haqqah: 11., al-Jin: 16., al-Mursalat: 20, 27., an-Naba':14., 'Abasa: 25., at-Tariq: 6., Hud: 44., an-Nazi'at: 31. (Abdul Baqi: 1996)

Kata $M a^{\prime}$ yang ada di dalam Al-Quran tidak seluruhnya dimaksudkan air yang terdiri atas unsur oksigen dan unsur-unsur hidrogen. Makna kata $m a$ ' dalam al-Quran mencakup:

1. Terkait dengan proses penciptaan alam semesta atau sebagai salah satu kondisi terwujudnya alam semesta. Yaitu di dalam Surat Hud ayat 11:

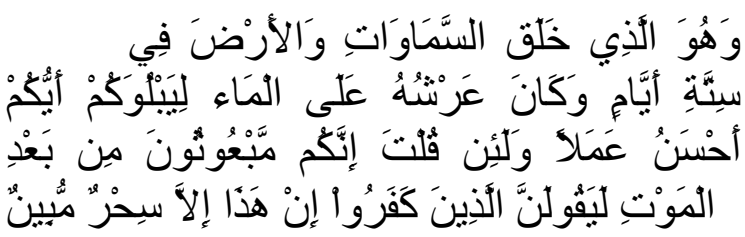

Artinya; Dan Dialah yang menciptakan langit dan bumi dalam enam masa dan adalah 'Arsy-Nya di atas air, agar Dia menguji siapakah di antara kamu yang lebih baik amalnya, dan jika kamu berkata (kepada penduduk Mekah):"Sesungguhnya kamu akan dibangkitkan sesudah mati", niscaya orang-orang yang kafir itu akan berkata:"Ini tidak lain hanyalah sihir yang nyata". (QS. 11:7)

Dengan kata lain, sebelum alam semesta terbentuk seperti sekarang ini, ia mengalami bentuk atau sifat yang oleh Steven Winberg dinamakan "sop kosmos atau zat cair". Karena saat itu umur alam semesta mendekati seperseratus sekon dan suhunya sekitar 100 milair derajat maka campuran partikel dan radiasi yang sangat tinggi itulah yang disebut dengan 'sop kosmos'. Adapun air yang kita kenal sekarang, yang terdiri atas unsur oksigen dan unsur-unsur hidrogen, di dalam fase penciptaan alam semesta belum dapat berbentuk dan isi alam ketika itu merupakan radiasi dan materi yang pada suhunya yang sangat tinggi dimana wujudnya lain daripada air yang sekarang ini.

2. Informasi tentang Penciptaan manusia, hal ini seperti yang dijelaskan pada beberapa surat dalam al-Qur'an: al-Furqan: 54, asSajadah: 8, al-Mursalat: 20, dan ath-Tariq: 6 , ayat-ayat ini menjelaskan tentang penciptaan manusia. Menurut ayat ini, manusia diciptakan dari ma', mai'n mahin, dan mai'n dafiq. Karena itu, kata $m a$ ' di sini lebih tepat dairtikan sebagai mani atau sperma.

3. Air yang disediakan untuk penghuni surga dan neraka, yaitu disebutkan dengan kata $m a$ ' yang di dalam surat Ibrahim: 16, dan surat al-Kahfi: 29, menunjukkan air yang disediakan untuk penghuni neraka. Sedangkan kata $m a^{\prime}$ yang ada di dalam surat Muhammad; 15, dan surat alWaqi'ah: 31 menginformasikan tentang $m a$ ' untuk penduduk surga. Karena itu, kata $m a$ ' yang ada di dalam ayat-ayat dalam kelompok tiga ini tidak tepat dipahami sebagai air yang ditemukan di dalam kehidupan sekarang ini, tetapi lebih tepat dairtikan dengan air atau zat cair yang sesuai pula dengan alamnya, yakni alam akhirat yang tentu saja sifat dan bentuknya tidak lagi sama dengan yang ada di dunia. (Sahabuddin et al., 2007)

\section{Air Merupakan Sumber Kehidupan}

Kehidupan di bumi ini tidak akan terjadi jika pola dari seluruh penghuni alam ini tidak memiliki desain yang sempurna melalui sebuah ketetapan yang indah dan sempurna sesuai dengan yang telah ditetapkan oleh Allah Swt. Dengan demikian, sedikit saja terjadi ketimpangan dalam desain tersebut akan mengubah tidak hanya bumi, tetapi semua yang berada di dalamnya. Bumi telah memiliki desain sempurna dengan ketetapan yang indah. Tujuannya, agar manusia dan makhluk hidup bisa eksis di dalamnya. Desain tersebut antara lain keberadaan bumi yang jauh dari matahari, selain itu bumi juga dibekali kekuatan untuk 
berotasi pada pusatnya dan juga berevolusi mengelilingi matahari. Di samping itu, bumi juga dibekali kecenderungan dan fleksibilitas dalam menghadapi perubahan, medan magnetisnya yang kuat, dan juga ketebalan keraknya.

Cakrawala bumi yang telah dibuat dengan desain yang sempurna, karena pada awal pembentukannya dibentuk dari gas hidrogen, amonia dan metan. Adapun uap air telah memainkan peranan yang sangat penting dalam pembentukan meterial organisme yang menjadi keharusan munculnya kehidupan. Dengan melihat peranan penting yang dimainkan oleh air untuk menciptakan kehidupan di muka bumi ini. Maka perlu ada kajian khusus yang menjelaskan sebagian kenyataan ilmiah yang terkait dengan keistimewaan air. Sirkulasi yang dimainkan oleh air dalam kehidupan di muka bumi ini adalah pembuktian dari firman Allah:

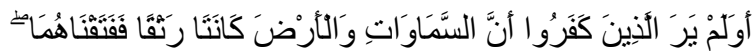

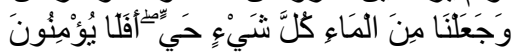

Dan apakah orang-orang yang kafir tidak mengetahui bahwasanya langit dan bumi itu keduanya dahulu adalah suatu yang padu, kemudian Kami pisahkan antara keduanya. Dan dari air Kami jadikan segala sesuatu yang hidup. Maka mengapakah mereka tiada juga beriman?

Para ahli Geologi memperkirakan kuantitas air yang terdapat di bumi mencapai 16 milair $\mathrm{km}^{3}$ atau setara dengan 16 triliun ton. Artinya, rasio kandungan air dalam bumi mencapai 25 ribu. Bagian terbesar dari kandungan air ini, yaitu sekitar 13 miliah $\mathrm{km}^{3}$ berada di lapisan bumi, dibawah kerak bumi. Kandungan tersebut berupa uap air yang ditekan oleh panas yang tinggi dari dalam bumi. Kandungan air sisanya, yaitu sekitar 3 milair $\mathrm{km}^{3}$, setengahnya sebagai penyusun gurun dan tambang yang ada di kerak bumi, dan setengah lainnya terkumpul di samudra, lautan dan sungai-sungai. Sebagian besar air yang berada di permukaan bumi terkumpul di samudra dan lautan. Adapun sisa sekitar 100 $\mathrm{km}^{3}$ air terdapat di tanah, di sela-sela kerak bumi, terdapat di danau, sungai, dan tanah dalam bentuk air yang mengalir, juga terdapat di pegunungan dan daerah kutub dalam bentuk air yang membeku.
Para ahli meyakini bahwa air yang ada di permukaan bumi keluar dari dalam bumi. Setelah kerak bumi tersusun menjadi keras, air mulai keluar dari dalam bumi dalam bentuk uap bersama lava yang disemburkan oleh gununggunung berapi dari dalam bumi ke permukaan bumi. Pendapat ini dibenarkan dengan firman Allah Surat an-Nazi' at 30-31:

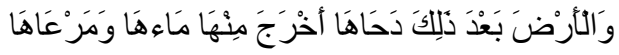

Ia memancarkan daripadanya mata airnya dan (menumbuhkan) tumbuhtumbuhannya. Dan bumi sesudah itu dihamparkan-Nya.

Para ahli Geologi memperkirakan jumlah air yang keluar dari dalam bumi pada tahun pertama sekitar 1 juta $\mathrm{km}^{3}$ atau sekitar 1.000 juta ton. Para ahli juga meyakini bahwa jumlah air tersebut cukup untuk membentuk batasan air yang indah di muka bumi seiring berekembangnya bumi selama jutaan tahun. Wujud air pada awal pembentukan bumi masih berupa gas yang memenuhi cakrawala bumi. Hal ini dikarenakan permukaan bumi ketika itu masih panas. Stelah permukaan bumi menjadi dingin, uap-uap tersebut mulai memadat dan kemudian jatuh ke bumi berupa air hujan yang deras.

Air memainkan peranan dalam pembentukan sebagian relief bumi, seperti lembah-lembah dan tanah-tanah datar. Meskipun semua air bumi telah keluar dari dalam bumi dan terkumpul di permukaan bumi menjadi samudra yang sangat luas dengan ketinggair air mencapai $3 \mathrm{~km}$, tetapi dengan kasih sayang dan rahmat Allah terhadap manusia, air yang telah dimanfaatkan tersebut tidak habis dan masih memiliki cadangan berupa uap-uap yang tertahan di bawah kerak bumi. Simpanan air yang besar di bawah kerak bumi tersebut akan menggantikan air yang berada di muka bumi ketika berkurang.

Kekurangan tersebut dikarenakan naiknya air ke udara atau karena dikonsumsi terus-menerus oleh unsur-unsur pembentuk bumi. Meskipun bumi masih berbentuk bola yang licin seperti bentuk awalnya, tetapi jumlah air yang berada di permukaan bumi tersebut tertutup dan tidak dapat naik lebih dari $3 \mathrm{~km}$. akan tetapi dengan ketentuan dari Allah Swt dan karena tekanan air yang besar terhadap permukaan bumi yang dibuat dalam keadaan lunak dan tipis, permukaan bumi mulai melandai di bawah tekanan tersebut. Seiring semakin bertambahnya volume air pada daerah 
tersebut, maka daerah tersebut semakin melandai.

Proses ini telah menyebabkan air terkumpul pada satu titik di muka bumi yang lebih rendah dari bagian bumi lainnya karena permukaannya naik oleh tekanan dari dalam bumi sehingga membentuk daratan. Kenyataan ini semkin bertambah kuat ketika para ahli geologi mengungkapkan bahwa samudrasamudra semula adalah satu samudrera, begitu pula benua-benua yang ada berasal dari satu benua. Akan tetapi, karena peretakan lapisanlapisan pembentuk kerak bumi, mulailah benua yang tunggal tersebut terpecah menjadi beberapa benua dalam proses yang sangat pelan, demikian yang dinamakan erosi benua.

Samudra sekarang ini menutupi sekitar $70 \%$ permukaan bumi, sedangkan $30 \%$ lainnya adalah daratan. Rara-rata ketinggan daratan dari permukaan laun hampir satu kilometer, sedangkan kedalaman laut dari permukaannya kurang lebih empat kilometer. Penelitian para ahli menjelaskan ahwa bertambah atau berkurangnya permukaan bumi terjadi tanpa mengubah kehidupan di bumi. Rata-rata temperatur permukaan bumi akan berbeda antara satu tempat dengan tempat lainnya, yakni berkisar $25^{\circ} \mathrm{C}$. perbedaan ini terjadi disebabkan perbedaan yang besar jenis temperatur dari tanah di daratan dan air di lautan. Begitu juga jumlah karbon dioksida yang berada di lapisan udara akan berubah karena perbedaan daya serat daratan dan lautan terhadap gas yang menjadi sumber utama kehidupan makhluk hidup.

Volume curah hujan yang mengenai daratan tergantung pada perbandingan luas daratan dan lautan. Ada pendapat yang menyatakan bahwa kuantitas air yang terdapat di samudra adalah lebih banyak daripada kebutuhan makhluk hidup. Samudra dengan kedalaman yang sedang dianggap cukup untuk memenuhi kebutuhan makhluk hidup. Akan tetapi, terdapat hikmah yang besar dari keberadaan jumlah air yang begitu banyak, yakni air hujan yang akhirnya kembali lagi ke laut melalui sungai-sungai membawa sejumlah garam dan tanah kering, sehingga menambah kadar garam dalam air laut seiring berjalannya waktu.

Bertambahnya kadar garam dalam laut melebihi kadar yang telah ditentukan akan mendatangkan kematian semua makhluk hidup di dalamnya. Bukti paling nyata dari kelebihan kadar garam laut tersebut adalah laut mati di
Yordania. Akan tetapi, dengan kekuasaan Allah dan juga karena jumlah air yang sangat banyak di laut, kadar garam laut masih saja berada pada batas yang bisa untuk didiami makhluk hidup.

Proses perpindahan air dari samudra dan menyebar ke daratan adalah melalui proses yang sangat terukur. Energi matahari dimanfaatkan untuk menguapkan air samudra di bwah temperatur titik didih. Sebagaimana firman Allah dalam surat al-Mukminun: 18.:

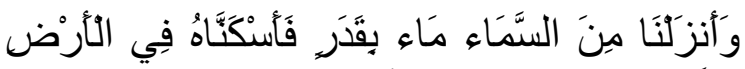

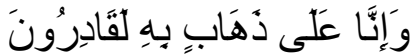

Artinya;"Kami telah menurunkan air dari langit dengan kadar tertentu. Kami diamkan air itu di bumi dan Kami mampu untuk menghilangkannya"

Para ahli memperkirakan jumah air yang menguap dari samudra dalam satu tahun adalah $400.000 \mathrm{~km}^{3}$ dan air dari daratan sebesar $60.000 \mathrm{~km}^{3}$. Untuk menguapkan air dalam jumlah tersebut diperlukan tenaga yang sangat besar dalam satu tahun. Matahari memiliki persediaan energi yang banyak untuk menguapkan air dalam jumlah tersebut, yaitu melalui sinar yang sampai ke bumi berupa gelombang cahaya dan gelombang panas. Penelitan para ahli mengatakan bahwa energi uap tidak hilang secara percuma, tetapi energi tersebut berubah membeku di udara dan mempengaruhi udara bumi terutama di malam hari. Ketika air yang yang menguap naik ke lapisan udara tertinggi bersama gelombang udara yang naik, mulailah uap menebal dalam bentuk awan karena suhu yang sangat dingin di lapisan udara teratas hal ini sangat tepat dengan apa yang telah diturunkan Allah sejak 14 abad yang lalu dalam firmanNya surat al-A'raf: 57

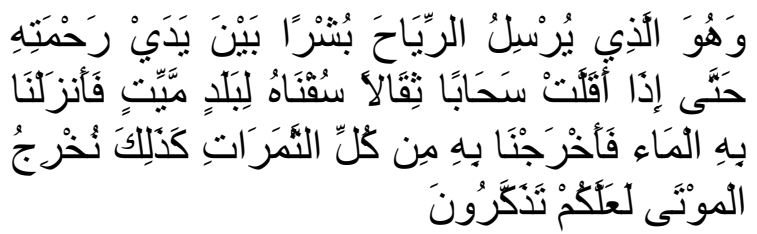

Artinya;Dan Dialah yang meniupkan angin sebagai pembawa berita gembira sebelum kedatangan rahmat-Nya (hujan); hingga apabila angin itu telah membawa awan mendung, Kami halau ke suatu daerah yang tandus, lalu Kami turunkan hujan di daerah itu, maka Kami keluarkan dengan sebab 
hujan itu pelbagai macam buahbuahan. Seperti itulah Kami membangkitkan orang-orang yang telah mati, mudah-mudahan kamu mengambil pelajaran.

Dan setelah uap air naik ke lapisan udara yang berbeda-beda, uap tersebut memadat dan menjadi awan yang nantinya terbawa oleh angin ke tempat-tempat yag kering dan terakhir awan tersebut berubah menjadi tetesan air yang turun sebagai air huan, salju dan embun. Mahabenar Allah Swt yang berfirman:

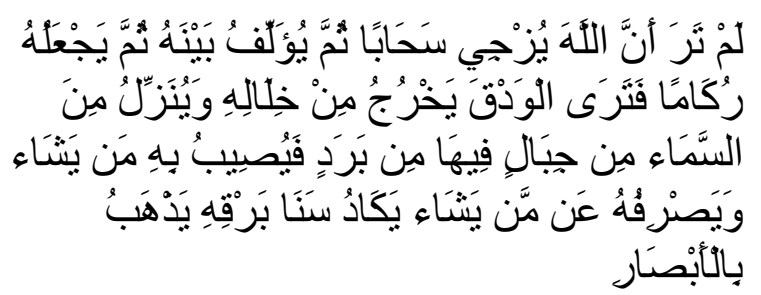

Artinya Tidakkah kamu melihat bahwa Allah mengarakawan,kemudian engumpulkan antara (bagian-bagian)nya, kemudian menjadikannya bertindih-tindih, makakelihatanlah olehmu hujan keluar dari celah-celahnyadan Allah (juga) menurunkan (butiran-butiran) es darilangit, (yaitu) dari (gumpalangumpalan awan seperti)gununggunung, maka ditimpakan-Nya (butiran-butiran)es itu kepada siapa yang dikehendaki-Nya dandipalingkanNya dari siapa yang dikehendakiNya.Kilauan kilat awan itu hampirhampir menghilangkanpenglihatan. (QS Al-Nur: 43-44)

Jika air dalam jumlah yang sangat besar tersebut diperkirakan turun dalam sekali tuangan ke permukaan bumi, maka akan terjadi banjir setinggi sepuluh meter di seluruh daratan. Akan tetapi, dengan rahmat dan kasih sayang Allah Swt terhadap hambaNya, 370.000 $\mathrm{km}^{3}$ air turun ke samudra dan hanya 90.000 $\mathrm{km}^{3}$ yang turun di daratan. Jika jumlah 90.000 $\mathrm{km}^{3}$ dibagikan ke semua daratan dengan merata, maka bagian untuk setiap satu meter persegi tanah mendapat $1 \mathrm{~m}^{3}$, sebagai wujud kasih sayang Allah terhadap hamba-Nya, air tersebut turun dalam beberapa tahap. (Hisyam Thalabah at.al., 2009)

Kepeloporan al-Quran terlihat jelas dalam memberi indikasi tentang keseimbangan keberadaan air di bumi dan kebutuhan manusia di atasnya sekaligus menunjukkan ketidakmampuan manusia menurunkan hujan atau mengatur tempat turunnya, kualitas dan waktunya serta kuantitasnya, kalau bukan karena rahmat dan karunia Allah Swt bagi hamba-Nya maka Allah mengatur siklus air di bumi ini secara khusus dan tidak adanya siklus air di planet lainnya. Ini adalah salah satu bukti ilmiah di dalam al-Quran yang diturunkan Allah Swt dengan ilmu-Nya, yang sekaligus menjadi bukti bahwa al-Quran adalah firman Allah Swt dan menjadi bukti bahwa nabi Muhammad Saw adalah utusan dan RasulNya yangmenerima wahyu melalui sifat kenabian dan kerasulannya.

\section{DAFTAR PUSTAKA}

Abdul Baqi, Muhammad Fu'ad., 1996, Mu'ajam al-Mufahras li alfadzh alQur'an al-Karim. Kairo: Darul Hadis, 779-780.

Al-Faruqi,Ismail Raji. 1988. Tauhid. Bandung: Pustaka. 53.

Ishfahani, Raghib. T.t. Mu'jam Mufradat Alfadz al-Qur'an, T.tp. 498.

El-Naggar, Zaghloul., 2010, Selekta dari Tafsir Ayat-Ayat Kosmos dalam al-Qur'an alKarim jilid 3,Jakarta: Shorouk International Bookshop, 72.

Sahabuddin et al. 2007, Ensiklopedia AlQuran: Kajian Kosakata, Jakarta: Lentera Hati, 536-537 